UDC 303.732

DOI: $10.20535 /$ SRIT.2308-8893.2021.2.05

\title{
METHODS FOR RESEARCHING THE SUSTAINABILITY OF PRODUCTION PROCESSES WHEN IMPLEMENTING A CYBER-PHYSICAL SYSTEM
}

\author{
A. KUDRIAVTCEVA
}

\begin{abstract}
The article presents an analysis of the methods and criteria for assessing sustainability and the development of stabilization systems, proposed in the theory of automatic control, and studies of approaches to ensuring sustainability, proposed and applied in the practice of controlling production processes. It is proposed to develop models when introducing a cyber-physical system of a production enterprise, combining the ideas of stabilization systems developed in the theory of automatic control, and methods of the theory and practice of managing production processes, while controlling the sustainability based on the laws and methods of systems theory and system analysis.
\end{abstract}

Keywords: control, production process, sustainability, stabilization.

\section{INTRODUCTION}

The active development of innovative technologies has influenced the emergence of a new concept of the cyber-physical system (CPS), which implies the integration of computing resources into physical processes.

Systems of this class should be considered as open systems with active elements, since the properties of cyber-physical systems in the interaction of innovative technologies approach the properties of living systems, which is important to take into account when studying stability.

The relevance of the study of the features and prospects for the development of cyber-physical systems is confirmed by the famous economist and ideologist of the fourth industrial revolution K. Schwab. In his research, the author claims that in terms of its scale, volume and complexity, "The fourth industrial revolution has no analogues in the previous experience of mankind. New technologies unite physical, informational and biological worlds and are capable of creating, on the one hand, huge opportunities, on the other, a potential threat" [1].

Due to the initiatives of active elements and innovations, problems arise of maintaining the stability of production processes, which, when innovative technologies interact, have the specific properties of open systems, which requires a revision of the methods and criteria for assessing their stability. Moreover, the sustainability management system should reflect changes in the activities of the enterprise, assess their dynamics and predict the future state of the system. The article provides a brief overview of methods for assessing stability in the theory of automatic control, as well as methods for ensuring stability in the control of production processes. A combination of the principles of stabilization, proposed in the theory of automatic control, and the experience of assessing stability, used in 
the practice of enterprise management, is proposed. Such a combination is proposed to be made on the basis of an informational assessment of the degree of integrity, which allows providing emergent properties arising in a cyber-physical system as a result of the interaction of components.

Emergent properties in CPS arise due to the flexibility of the interaction of components, which allows rebuilding processes in CPS, eliminating emerging failures of production processes, rebuilding processes taking into account changes in customer requirements, etc. Such a state of the system approaches the behavior of living systems, which is called mobile equilibrium in the theory of open systems.

\section{ASSESSMENT OF SUSTAINABILITY IN THE THEORY OF AUTOMATIC CONTROL}

For technical systems, a theory of sustainability was developed, the foundations of which were laid by A. Poincaré and A.M. Lyapunov. The basis of this theory is the mapping of situations by differential equations and methods for studying the stabilization of systems, i.e. the ability of systems to return to a state of equilibrium after it has been removed from this state under the influence of external (or in systems with active elements - internal) disturbing influences.

In this theory of automatic control, a fairly large number of methods and models for ensuring stability, criteria for determining stability, were formed: the Routh-Hurwitz, Nyquist, Mikhailov criteria.

Based on the analysis of these methods in relation to the problem under consideration, it is useful to investigate the possibility of using the following stabilization systems.

1. Locally optimal systems with minimization of the norm of the control vector and a given decrease in the function A.M. Lyapunov for linear objects [2].

The solution $x^{*}(t)$ of the system of differential equatcions $\dot{x}=A x+B u$ with the initial conditions $x(0)=x_{0}$ is Lyapunov stable if for any $\varepsilon>0$ there exists $\delta=\delta(s)>0$, such that if

$$
\left\|x\left(t_{0}\right)-x^{*}\left(t_{0}\right)\right\|<\delta \text {, then }\left\|x(t)-x^{*}(t)\right\|<\varepsilon \text { for all } t \geq 0 .
$$

The solution $x^{*}(t)$ of the system $\dot{x}=A x+B u$ is asymptotically stable if it is Lyapunov stable and the condition is satisfied:

$$
\lim \left\|x(t)-x^{*}(t)\right\|=0 \text { as } t \rightarrow \infty \text { provided }\left\|x(0)-x^{*}(0)\right\|<\delta .
$$

In this case, all solutions that are sufficiently close to $x^{*}(0)$ at the initial moment of time gradually converge to $x^{*}(t)$ as $t$ increases.

If the solution $x^{*}(t)$ is asymptotically stable and, moreover, from the condition $\left\|x(0)-x^{*}(0)\right\|<\delta$ it follows that $\left\|x(t)-x^{*}(t)\right\| \leq \alpha \quad\left\|x(0)-x^{*}(0)\right\| e^{-\beta t}$ for all $t \geq 0$, then the solution $x^{*}(t)$ is exponentially stable. In this case, all solutions close to $x^{*}(0)$ at the initial moment converge to $x^{*}(t)$ at a rate (greater or equal), which is determined by an exponential function with parameters $\alpha, \beta[3]$. 
The Lyapunov stability condition for systems is formulated as follows: "in a stable system, the free component of the solution to the equation of dynamics, written in deviations, should tend to zero, that is, decay" [2]. This implies the stability condition for linear dynamical systems: the linear system will be stable if all real roots and all real parts of the complex roots of the characteristic equation corresponding to the original differential equation of free motion of the system are negative, which gives exponentially decaying solutions [4].

2. Locally and interval optimal systems with minimization of the norm of bounded coordinates and controls of nonlinear objects.

Let the equations of the object $x_{k+1}=H x_{k}+F u_{k}, y_{k}=x_{k}, x_{k 0}=x_{0} \mathrm{e}$ stabilized by controls $u_{k}=\gamma u_{k}^{*} \gamma \Phi\left(H x_{k}\right)$ The equation of a closed nonlinear locally optimal system has the form: $x_{k+1}=H x_{k}+F u_{k}^{*} \gamma \Phi\left(H x_{k}\right) \quad x_{k 0}=x_{0}$. For the system to be stable, it is sufficient that the scalar parameter $\gamma$ atisfies the following algebraic inequality [5]

$$
\gamma\left(2 L_{\Phi} F+\gamma L^{2}{ }_{\Phi} F^{2}\right) P H^{2}<-\lambda\left(\widetilde{Q}_{2}\right),
$$

where $\lambda\left(\widetilde{Q}_{2}\right)$ is the minimum eigenvalue of some symmetric and positive definite matrix $\widetilde{Q}_{2}: \lambda\left(\widetilde{Q}_{2}\right)=\min _{j} \lambda_{j}\left(\widetilde{Q}_{2}\right)$.

3. Locally or interval optimal systems with optimization of linear functionals on the trajectories of nonlinear systems with an additive right-hand side (in coordinates and controls) with bounded coordinates and controls.

4. Systems for optimal stabilization of programmed movements for objects specified in paragraphs $1-3$.

Let the difference operator of a linear or linearized dynamic object have the form: $x_{k+1}=H x_{k}+F u_{k}, x_{k 0}=x^{0}$. As a result, the problem of calculating controls for discrete time "plunges" into a countable number of problems: calculate a family of numerical vectors that are solutions to optimization problems [6]:

$$
\begin{aligned}
u_{k}^{*} & =T_{u}\left(\begin{array}{c}
s_{k^{*}} \\
y_{k^{*}}
\end{array}\right)=\operatorname{argmin}\left\{\varphi\left(z_{k}\right)=z_{k}-C_{z 2}^{2}=\| \begin{array}{c}
s_{k}-C_{s} \|_{k}^{2} \mid \bar{A} z_{k}=b_{z k} ; \\
y_{k}
\end{array}\right. \\
\bar{A} z_{k} & =\left[\begin{array}{cc}
A & 0 \\
\frac{1}{2} & -E_{n}
\end{array}\right]\left[\begin{array}{l}
s_{k} \\
y_{k}
\end{array}\right]=\left[\begin{array}{c}
b_{x k} \\
\frac{1}{2} d_{k}
\end{array}\right]=\left[\begin{array}{c}
H x_{k} \\
\frac{1}{2} d_{k}
\end{array}\right]=b_{z k} ; \bar{A}=\left[\begin{array}{cc}
A & 0 \\
\frac{1}{2} & -E_{n}
\end{array}\right] ; \\
A & \left.=[E \mid-F], \quad z_{k}=\left[s_{k} \mid u_{k}\right]^{\mathrm{T}}, \quad s_{k}=\left[x_{k+1} \mid u_{k}\right]^{\mathrm{T}}, \quad z_{k}=z_{k 2}^{2} \leq r^{2}\right\} .
\end{aligned}
$$

5. Systems of optimal stabilization based on the $R$. Bellman equation with bounded controls (the problem of Corresponding Member of the USSR Academy of Sciences A. M. Letov).

For the equations of perturbed motion $\dot{x}=f(x, u, t), x\left(t_{0}\right)=x^{0}$ the quality functional [5]:

$$
J=\int_{t}^{t_{k}} \omega(x, u, \tau) d \tau+\Phi\left(x\left(t_{k}\right), t_{k}\right) .
$$


And the Lyapunov-Bellman function for the moments of time $t$ and $t+s$ will look like this:

$$
\begin{aligned}
& V(x, t)=\min _{u}\left[\int_{t}^{t_{k}} \omega(x, u, \tau) d \tau+\Phi\left(x\left(t_{k}\right), t_{k}\right)\right] \\
& V(x(t+s), t+s)=\min _{u}\left[\int_{t}^{t_{k}} \omega(x, u, \tau) d \tau+\Phi\left(x\left(t_{k}\right), t_{k}\right)\right] .
\end{aligned}
$$

Control $u$ should deliver the minimum $J$ for any value $s>0$. Then the necessary optimality condition - the Bellman equation $\min _{u}[\dot{V}(x)+\omega(x, u, t)]=0$ provides the minimum of the integral functional.

The above examples illustrate the development of stabilization systems in the theory of automatic control, which can be useful in developing models for managing production processes when introducing innovative technologies.

However, the concepts of balance, stabilization, stability in cyber-physical systems, despite the seeming analogy with technical ones, are much more complex concepts, and the methods of the automatic control theory are insufficient. Therefore, the next section examines foreign and domestic works containing methods for assessing the sustainability of production processes, developed in the theory of organizational management.

\section{ANALYSIS OF SUSTAINABILITY IN MANAGEMENT AND THEORY OF ORGANIZATIONAL MANAGEMENT}

Marc A. Rosen [7] considers engineering sustainability, namely sustainability, which is an essential component of overall sustainability for human activity and development. The author believes that options and ways to ensure engineering stability can be achieved taking into account the key factors:

1. Sustainable resources.

2. Sustainable processes.

3. Increased efficiency.

4. Reducing the impact on the environment.

5. Implementation of other aspects of sustainability.

The article also shows that the use of efficiency tools such as environmental tool analysis and life cycle analysis is essential to achieve engineering sustainability. The concept of zero energy smart buildings and communities illustrates well the author's ideas.

Evgenia Pavlovskaia [8] explores and analyzes the concepts of sustainability criteria for sustainable production. The article discusses important critical issues necessary for a deeper understanding of the sustainability criteria and their practical use. Sustainability Criteria Indicators refer to the instruments used to test and evaluate the fulfillment of the sustainability criteria and progress towards sustainability. Indicators can provide quantitative measurement and qualitative assessment of human activity and its impact on the outside world [9], and should also reflect the fulfillment of sustainability criteria. 
The research results highlight that sustainability criteria are not a welldefined concept. Their content should be linked to an understanding of what is sustainable development and sustainability in each specific industry.

The objectives of the sustainability criteria need to be explained and refined so that they are easier to interpret and fulfill. A preliminary list of the main indicators of sustainable production, according to the author, may include the following parameters:

1. Use of energy and materials in the production process: energy and materials are saved, and the form of the applied energy and materials is most suitable to achieve the desired result.

2. Natural environment, including human health: waste and environmentally incompatible by-products are constantly being reduced, removed or recycled; chemicals, physical agents, technologies and methods of work that pose a danger to humans.

3. Economic performance: Management is committed to an open, participatory process of continuous assessment and improvement focused on long-term economic performance.

4. Products: products and packaging must be safe and environmentally friendly throughout their entire life cycle; services are designed to be safe and environmentally friendly [10].

The content of the list will differ depending on what is the subject of the definition of sustainability: environmental protection, industrial development, consumer interests.

In [11], the authors consider a holistic assessment of sustainability in production. The study on the assessment of the sustainability of production [12] presents a structure for building a comprehensive assessment matrix of the entire life cycle of a product, showing the following six elements of sustainability of production:

1. Impact on the environment.

2. Impact on society (safety, health, ethics, etc.).

3. Functionality.

4. Optimal use of resources.

5. Performance.

6. Possibility of recycling / product recovery.

Moreover, the authors emphasize that modern sustainable production systems must be planned and managed as holistic socio-technological-ecological systems in terms of the entire life cycle [13], which requires the ability to think and communicate systematically, or systems thinking becomes an important ability that must be developed to enhance the design and control of such systems [14].

The authors also argue that sustainable manufacturing starts with developing a new product that can use the right materials and manufacturing processes. This is because the manufacturing system requires new innovations and more sustainable approaches to manufacturing. As raw materials are depleted, advanced materials research requires clearer research and training for engineers and scientists [11].

Design and manufacturing methods, according to the authors of [15], currently have to undergo major changes to include problems that cover the entire 
traditional product life cycle. New design methodologies, innovative manufacturing technologies, and effective tools must be developed concurrently and address common life cycle issues, including (Fig. 1):

- Reduced production costs.

- Reduced product development time.

- Reduced material use.

- Reduced energy consumption.

- Reduction of industrial waste.

- Repair, reuse, refurbishment and recycling of used ones.

- Products / materials.

- Environmental and social issues.

This paradigm shift in product design and manufacturing requires the development of optimization models that incorporate environmentally friendly, energy efficient, lean manufacturing methods that take into account disassembly, reuse, re-production and recycling. It promotes systems thinking when developing new products and processes and requires attention to the interests of all stakeholders. This requires the development of new design methodologies, manufacturing processes, post-use processes, and enterprise resource planning to simultaneously achieve multiple production efficiency goals.

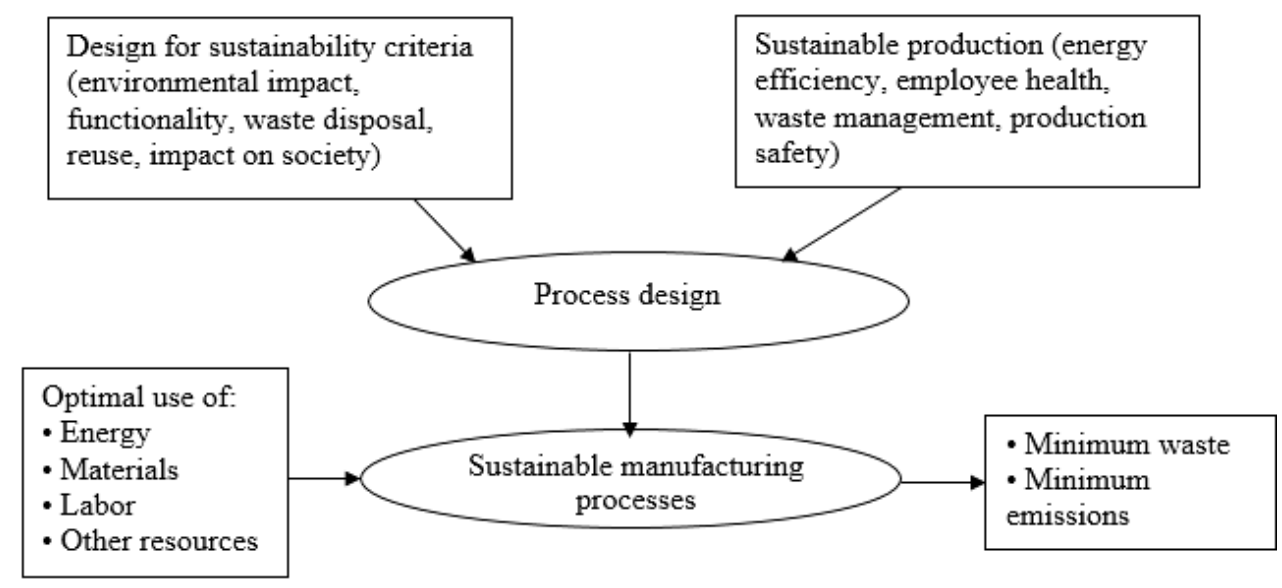

Fig. 1. Sustainable Manufacturing Process Diagram

Ljungberg L.Y. [16] reviews current practices for sustainable product development and identifies four major challenges inherent in sustainable production:

- Excessive consumption.

- Utilization of resources.

- Pollution.

- Excess population

The author also argues that excessive consumption of energy, packaging and transportation has serious consequences in the long term.

Shotylo D.M. [17] define the sustainability of the production system as the ability of the production system in the course of its activity under the influence of the environment to achieve the specified goals in the established time interval, without changing the elements, structure and processes included in it. At the same time, the essence of sustainability is manifested in the ability of the production system to preserve the integrity of the entire structure and its individual links, to 
perform stable functions assigned to it and preserve its main functional parameters, to maintain a stable level of output characteristics in the presence of various kinds of external and internal deviating influences, to timely material and technical, transport and information services at a given level of quality of these processes (Table 1).

Table 1. The essence of sustainability in a production system

\begin{tabular}{|c|}
\hline The essence of sustainability of the production system \\
\hline $\begin{array}{c}\text { The ability of the production system to maintain the integrity of the entire structure and } \\
\text { its individual links }\end{array}$ \\
\hline The ability of the production system to stably perform the assigned functions \\
and maintain its basic functional parameters \\
\hline $\begin{array}{c}\text { The ability of a production system to maintain a stable level of output characteristics } \\
\text { in the presence of various kinds of external and internal deflecting influences }\end{array}$ \\
$\begin{array}{c}\text { The ability of the production system to provide timely and uninterrupted material, tech- } \\
\text { nical, transport and information services at a given level of quality } \\
\text { of these processes }\end{array}$ \\
$\begin{array}{c}\text { The ability of the production system to maintain established economic ties within the } \\
\text { production chain (stable ties with suppliers, consumers, financial institutions) }\end{array}$ \\
\hline $\begin{array}{c}\text { The ability of the production system to maintain its competitive position } \\
\text { in the market }\end{array}$ \\
\hline $\begin{array}{c}\text { The ability of a production system to restore its elements, processes and functions } \\
\text { in the original state, or close, established within specified limits }\end{array}$ \\
\hline The ability of a production system to withstand environmental influences \\
\hline
\end{tabular}

\section{PROSPECTS FOR THE DEVELOPMENT OF METHODS FOR RESEARCHING THE SUSTAINABILITY OF CYBER-PHYSICAL SYSTEMS}

With the development of cyber-physical systems, the components of production processes continuously exchange information with computing platforms, sensors, network structure, operators, i.e. emerging situations need to be displayed using an open system model with active elements.

With the interaction of CPS elements, the emergence effect may occur, the appearance of new properties that are absent in the elements. For example, it becomes possible to adjust the production process, eliminate failures. At the same time, negative effects are also possible, which can lead to instability of the production process.

To manage the sustainable development of a cyber-physical system, it is necessary to constantly monitor the state of maintaining its integrity. For this, models are being developed based on the application of the information approach of A.A. Denisov [18], who introduced comparative quantitative assessments of hierarchical structures in terms of the degree of integrity. Research has shown that any developing system is between the state of absolute integrity and absolute freedom of elements:

$$
\alpha+\beta=1,
$$

where $\alpha=-C_{m} / C_{i}$ is the degree of integrity, and $\beta=C_{s} / C_{i}$ is the utilization rate of elements as a whole; $C_{s}, C_{i}, C_{m}$ - systemic, intrinsic and mutual com- 
plexities of the system; $J$ - information of perception; $H$ informational essence (potential); $C$ assessment of the information complexity of the system $C=J$.

Studies of the processes of interaction between the part and the whole in the system have shown that with a tendency towards a decrease in the degree of integrity, the system can disintegrate into parts that will function stably. But at the same time, useful properties arising as a result of the emergence effect will be lost. A large increase in the degree of integrity should provide stability. However, this can suppress the properties of active elements that provide useful properties for which the CPS is created.

Thus, it can be assumed that there should be a certain range of the degree of integrity $\alpha$ in which the CPS will function stably and perform the functions for which it is created. Then the problem arises of finding ways to measure $\alpha$. It seems promising to establish the relationship of this range with the criteria for assessing stability, developed in the theory of automatic control, and indicators proposed in the works discussed in section 2.

When managing the development of cyber-physical systems, the task of comparative analysis and selection of innovative technologies also arises, taking into account their characteristics, capabilities and usefulness. At present, some studies have already been carried out, published in articles [19-23].

Further development of the presented work presupposes the application of the methods of the laws of systems theory and the information approach of A.A. Denisov for the development of models of interaction of system elements.

\section{CONCLUSION}

The article presents an analysis of the methods and criteria for assessing stability and the development of stabilization systems, proposed in the theory of automatic control, and studies of approaches to ensuring stability, proposed in the practice of managing production processes.

It is proposed to develop models when introducing a cyber-physical system of a production enterprise, combining the ideas of stabilization systems developed in the theory of automatic control, and methods of controlling production processes, controlling stability based on assessing the degree of system integrity. Based on the study, it was concluded that the degree of integrity of such systems should be within certain limits, since: 1) an increase in the degree of integrity, determined by tighter control of the number and strength of interconnections between the CPS components, provides greater stability of the system's functioning, but at the same time less freedom of interaction of its components, which leads to a decrease in the possibility of manifestation of emergent properties; 2) a decrease in the degree of integrity (the degree of control of interactions between system components) leads to too independent behavior of the CPS components, a decrease in the stability of its functioning. The idea of using estimates of the degree of integrity and degree of freedom of elements was proposed in the information theory by A.A. Denisov [18], in which these assessments are used to study organizational systems and are obtained on the basis of assessing the structures of systems. For the study of processes in cyberphysical systems, such assessments are proposed to be applied for the first time.

With the continuation of the work, it is assumed 1) to develop models for assessing the degree of integrity in the context of complex graphs, displaying the interactions of components in cyber-physical systems, based on the fundamental 
principles of control, taken into account in the theory of automatic control when assessing the stability of systems; 2) taking into account that the models for evaluating arbitrary graphs can turn out to be difficult for practical application, studies will be carried out on the possibility of comparing information assessments of the degree of integrity with the criteria for assessing the sustainability of production processes when introducing a cyber-physical system used in the practice of managing enterprises, and determining the range of assessments of the degree of within which it is possible to realize the emergent properties of CPS while maintaining sufficient stability.

\section{REFERENCES}

1. K. Shvab, Chetvertaya promyshlennaya revolyutsiya [The Fourth Industrial Revolution]. Moscow: «E» Publ., 2017, 208 p.

2. A.M. Lyapunov, The general problem of motion stability; Vol. 2. M.: Izd-vo AN SSSR Publ, 1956.

3. A.A. Voronov, Fundamentals of the theory of automatic control. M.: Energiya, $1980,312 \mathrm{p}$.

4. Theory of automatic regulation; ed. V.V. Solodovnikova. M.: Mashinostroyeniye Publ., 1967.

5. V.N. Kozlov, V.E. Kupriyanov, and V.N. Shashikhin, Management of energy systems; part 1. Theory of automatic control. St. Petersburg: Publishing house of Polytechnic University, 2008.

6. A.A. Efremov, V.N. Kozlov, and V. Karakchieva, Part 2: collection of scientific papers of the XXIV International Scientific and Educational-Practical Conference, October 13-14, 2020; under total ed. V.N. Kozlova, A.N. Firsova. SPb.: POLYTECHEXPRESS, 2020.

7. Marc A. Rosen, "Engineering Sustainability: A Technical Approach to Sustainability", Sustainability, 2012.

8. Evgenia Pavlovskaia, "Sustainability criteria: their indicators, control, and monitoring (with examples from the biofuel sector)", Environmental Sciences Europe, 26, 2014.

9. National Research Council of the National Academies: Toward Sustainable Agricultural Systems in the 21st Century. Washington, DC: The National Academies, 2010.

10. V. Veleva and M. Ellenbecker, "Indicators of sustainable production: framework and methodology", J. Cleaner Product, 9(6), pp. 519-549, 2001.

11. Abdullahi Tijjani and Salem Abdullah Bagaber, "Sustainability Considerations in Manufacturing and Operation Management", International Journal of Scientific Engineering and Applied Science (IJSEAS), vol. 1, issue 4, July 2015.

12. F. Badurdeen, A. Jayal, and I. Jawahir, "Towardsa System Approach for Developing, Sustainable Products from Sustainable Manufacturing", in Bangalore Workshop, Bangalore India, 2009.

13. C. Soderquist and S. Overakker, "Education for sustainable development: a systems thinking approach", Global Environmental Research, 14, pp. 193-202, 2010.

14. F. Badurdeen et al., Sustainable Value Creation in Manufacturing at Product and Process Levels: Metrics-Based Evaluation, 2014.

15. I.S. Jawahir and Fazleena Badurdeen, "Innovation in sustainable manufacturing education", $11^{\text {th }}$ Global Conference on Sustainable Manufacturing, 2013.

16. L.Y. Ljungberg, "Materials selection and design for development of sustainable products", Materials \& Design, 28(2), pp. 466-479, 2007.

17. D.M. Shotylo, "The essence and content of the sustainability of the production system. Organization of production", ECONOMINFO, no. 6, 2006.

18. A.A. Denisov, Sovremennye problemy sistemnogo analiza: uchebnik [Modern problems of system analysis: a textbook]. SPb.: 3-e izd. Politekhn. un-ta Publ, 2008, 304 p. 
19. V.N. Volkova, A.V. Loginova, L.V. Chernenkaja, E.V. Romanova, Y.Y. Chernyy, and V.E. Lankin, "Problems of Sustainable Development of Socio-Economic Systems in the Implementation of Innovations", Proceedings of the 3rd International Conference on Human Factors in Complex Technical Systems and Environments, Ergo-2018, 3, pp. 53-56.

20. V.N. Volkova and Yu.Yu. Chernyi, "Application of Systems Theory Laws for Investigating Information Security Problems", Automatic Control and Computer Sciences, vol. 52, no. 8, pp. 1164-1170, 2018.

21. V.N. Volkova and V.Ye. Lankin, "Problema ustoychivosti sotsial'noekonomicheskoy sistemy $\mathrm{V}$ usloviyakh vnedreniya innovatsiy chetvertoy promyshlennoy revolyutsii [The problem of the sustainability of the socioeconomic system in the context of innovation of the fourth industrial revolution]", Ekonomika $i$ upravleniye: problemy i resheniya, 77 (6), pp. 25-29. 2018.

22. V. Volkova, A. Loginova, and A. Kudriavtceva, "Management of enterprise cyberphysical systems sustainable development while undergoing a digital transformation", IOP Conference Series: Materials Science and Engineering, 940(1), 2020.

23. V. Volkova, F. Tarasenko, V. Kozlov, and A. Kudriavtceva, "On further development of the control theory of automated complexes in the informationcommunication technologies implementation", Proceedings of the XI International Scientific Conference "Communicative strategies of Information Society”, 25-26 October 2019, Saint-Petersburg, Russia.

Received 24.12.2020

\section{INFORMATION ON THE ARTICLE}

Arina S. Kudriavtceva, Peter the Great St. Petersburg Polytechnic University, Russia, email: arinkin94@mail.ru

МЕТОДИ ДОСЛІДЖЕННЯ СТІЙКОСТІ ВИРОБНИЧИХ ПРОЦЕСІВ ПІД ЧАС УПРОВАДЖЕННЯ КІБЕРФІЗИЧНОЇ СИСТЕМИ / А.С. КУДрявцева

Анотація. Подано аналіз методів і критеріїв оцінювання стійкості і розроблення систем стабілізації, розроблених у теорії автоматичного керування, і досліджень підходів до забезпечення стійкості, пропонованих і застосовуваних у практиці керування виробничими процесами. Запропоновано під час упровадження кіберфізичної системи виробничого підприємства розробляти моделі, об'єднуючи ідеї систем стабілізації, розроблені в теорії автоматичного керування, і методи теорії і практики керування виробничими процесами, контролюючи стійкість на основі закономірностей і методів теорії систем і системного аналізу.

Ключові слова: керування, виробничі процеси, стійкість, стабілізація.

МЕТОДЫ ИССЛЕДОВАНИЯ УСТОЙЧИВОСТИ ПРОИЗВОДСТВЕННЫХ ПРОЦЕССОВ ПРИ ВНЕДРЕНИИ КИБЕРФИЗИЧЕСКОЙ СИСТЕМЫ

/А.С. Кудрявцева

Аннотация. Представлен анализ методов и критериев оценки устойчивости и разработки систем стабилизации, разработанных в теории автоматического управления, и исследований подходов к обеспечению устойчивости, предлагаемых и применяемых в практике управления производственными процессами. Предложено при внедрении киберфизической системы производственного предприятия разрабатывать модели, объединяя идеи систем стабилизации, разработанные в теории автоматического управления, и методы теории и практики управления производственными процессами, контролируя устойчивость на основе закономерностей и методов теории систем и системного анализа.

Ключевые слова: управление, производственные процессы, устойчивость, стабилизация. 